\title{
THE EFFECT OF EXERCISE ON INTERFERON GAMMA, BODY FAT AND BMI OF KIDNEY TRANSPLANT PATIENTS
}

\author{
EFEITO DO EXERCICIO SOBRE INTERFERON GAMA, GORDURA CORPORAL E IMC EM PACIENTES \\ COM TRANSPLANTERENAL
}

Original Article

ARTIGO ORIGINAL

Artículo Original

\author{
EFECTO DEL EJERCICIOSOBRE EL INTERFERÓN GAMMA Y EL IMCDE LOS PACIENTES CON \\ TRASPLANTEDERIÑÓN
}

\begin{abstract}
Elham Shakoor ${ }^{1}$
(Exercise Physiologist)

Mohsen Salesi ${ }^{1}$

(Exercise Physiologist)

Maryam Koushkie Jahromi

(Exercise Physiologist)

Hassan Sadeghi

(Corrective Exercise Specialist)

Mohammad Hossein Karimi ${ }^{3}$

(Immunologist)

Ashril Yusof ${ }^{4}$

(Exercise Physiologist)

1. Shiraz University, School of Education and Psychology,

Department of Physical Education and Sport Sciences, Shiraz, Iran.

2. Shiraz University of Medical

Sciences, Shiraz Geriatric Research

Center, Shiraz, Iran.

3. Shiraz University of Medical

Sciences, Transplant Research

Center, Shiraz, Iran.

4. University of Malaya, Department of Exercise Science, Center for Sports and Exercise Science Kuala Lumpur, Malaysia.
\end{abstract}

\section{Correspondence:}

Mohsen Salesi. Department of Physical Education and Sport Sciences, School of Education and Psychology, Shiraz University, Shiraz, Iran.mhsnsls@gmail.com

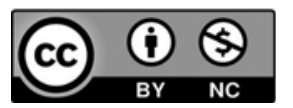

\begin{abstract}
Introduction: Poor physical function and obesity are well documented in kidney transplant patients. Significant health benefits result from regular physical activity, many of which are important for kidney transplant patients. Objective: The aim of this study was to investigate the effects of 10-week combined exercises on Interferon Gamma (IFNY), body fat percentage (BF\%) and body mass index (BMI) in kidney transplant patients. Method: In a randomized controlled experimental design, 44 kidney transplant patients aged 20-50 years were randomly divided into two groups of exercise $(n=23)$ and control $(n=21)$. The exercise group participated in a cumulative training program for 10 weeks, three days a week, $60-90$ minutes per day at $40-65 \%$ of predicted maximal heart rate reserve. A $5 \mathrm{ml}$ venous blood sample and anthropometric parameters were taken from the subjects at baseline and after 10 weeks. Results: The exercise group showed an improvement in BF\% (from 31.80 \pm 5.64 to $28.86 \pm 5.82, p=0.001$ ) and BMI (from $26.23 \pm 1.81$ to $25.45 \pm 2.11, p=0.001$ ), but there was no significant change in the IFNY level (from $0.06 \pm 0.02$ to $0.06 \pm 0.02, p=0.829$ ). There was a significant difference between the control and exercise groups for BF\% $(p=0.001)$ and BMI $(p=0.001)$. Conclusion: As a take-home message, it should be mentioned that combined exercise intervention is inexpensive and portable and can be performed at home or health centers for kidney transplant patients to reduce their weight and BF\%. Evidence Level l; High quality randomized trial with or without statistically significant difference, but with narrow confidence intervals.
\end{abstract}

Keywords: Exercise training; Body composition; Body fat distribution; Kidney transplantation.

\section{RESUMO}

Introdução: A função física deficiente e a obesidade são bem documentadas em pacientes com transplante renal. A atividade física regular resulta em benefícios significativos para a saúde, muitos dos quais são importantes para os pacientes com transplante de rim. Objetivo: O objetivo deste estudo foi investigar os efeitos de 10 semanas de exercícios combinados sobre interferon gama (IFN- $\gamma$ ), percentual de gordura corporal (GC) e índice de massa corporal (IMC) nesses pacientes. Métodos: Em um estudo randomizado experimental controlado, 44 pacientes com transplante renal com idade entre 20 e 50 anos foram divididos em um grupo exercício $(n=23)$ e um grupo controle $(n=21)$. O grupo exercício participou em um programa de treinamento cumulativo por 10 semanas, três dias por semana, 60 a 90 minutos por dia, com 40\% a 65\% da frequência cardíaca de reserva prevista. Foram coletadas amostras de sangue venoso de $5 \mathrm{ml}$, assim como os parâmetros antropométricos dos indivíduos no início do programa e depois de 10 semanas. Resultados: 0 grupo exercício apresentou melhora do percentual de GC $(31,80 \pm 5,64$ para $28,86 \pm 5,82, p=0,001)$ e do IMC $(26,23 \pm 1,81$ para $25,45 \pm 2,11, p=$ $0,001)$, mas não houve mudança significativa no nível de IFN- $\gamma(0,06 \pm 0,02$ para $0,06 \pm 0,02, p=0,829)$. Houve diferença significativa entre os grupos controle e exercício no percentual de $\operatorname{GC}(p=0,001)$ e no $\operatorname{IMC}(p=0,001)$. Conclusão: A mensagem a ser lembrada é que a intervenção com exercícios combinados é de baixo custo e os aparelhos necessários são portáteis, e pode ser realizada em casa ou em centros de saúde pelos pacientes de transplante renal, visando reduzir o peso e o percentual de GC. Nível de Evidência l; Estudo clínico randomizado de alta qualidade com ou sem diferença estatisticamente significante, mas com intervalos de confiança estreitos.

Descritores: Exercício; Composição corporal; Distribuição da gordura corporal; Transplante de rim.

\section{RESUMEN}

Introducción: el bajo funcionamiento físico y la obesidad están bien documentados en pacientes con trasplante de riñón. Los beneficios significativos para la salud son el resultado de la actividad física regular, muchos de los cuales son importantes para los pacientes con trasplante de riñón. Objetivo: El objetivo de este estudio fue investigar los efectos de los ejercicios combinados de 10 semanas sobre Interferón-Gamma (IFNY), porcentaje de grasa corporal (\% BF) e índice de masa corporal (IMC) en pacientes con trasplante renal. Método: en un diseño experimental controlado aleatorio, 44 pacientes con trasplante renal, de 20-50 años, se dividieron aleatoriamente en dos grupos de ejercicio ( $n=23)$ y control $(n=21)$. El grupo de ejercicio participó en un programa de entrenamiento acumulativo durante 10 semanas, tres días a la semana, 60 a 90 minutos por dia, com 40 a 65\% de la reserva máxima prevista para frecuencia 
cardiaca. Se tomaron $5 \mathrm{ml}$ de muestra de sangre de Venus y parámetros antropométricos de los sujetos en la línea de base al inicio y luego de 10 semanas. Resultados: El grupo de ejercicio mostró una mejora en el porcentaje de BF (de $31,80 \pm 5,64$ a 28,86 $\pm 5,82, p=0,001$ ) y el IMC (de 26,23 $\pm 1,81$ a 25,45 $\pm 2,11, p=0,001$ ), pero no hubo un cambio significativo en el nivel de IFNy (de $0.06 \pm 0.02$ a $0.06 \pm 0.02, p=0.829$ ). Hubo una diferencia significativa entre el control y los grupos de ejercicio para BF\% ( $p=0.001)$ e IMC ( $p=0.001)$. Conclusión: como mensaje de inicio se debe mencionar que la intervención combinada con ejercicios es económica y portátil, y puede realizarse en el hogar o en centros de salud para que los pacientes con trasplante de riñón disminuyan su peso y BF\%. Nivel de Evidencia l; Estudio clínico aleatorio de alta calidad, con o sin diferencia estadísticamente significativa, pero con intervalos de confianza estrechos.

Descriptores: Ejercicio; Composición Corporal; Tejido Adiposo; Trasplante de Riñón.

\section{INTRODUCTION}

End Stage Renal Disease (ESRD) patients are faced with several problems with respect to their disease and its treatment. ' Kidney transplantation is a treatment of choice and the most effective therapeutic strategy for patients with ESRD ${ }^{2}$ which can improve their quality of life so that the majority of patients can return to their normal life. ${ }^{3}$ Successful kidney transplantation is hampered by different complications including immune-mediated complications such as acute rejection. ${ }^{4}$ To prevent transplantation rejection, transplant patients need to use multiple immunosuppressive drugs including Azathioprine, Corticosteroids, Tacrolimus, Sirolimus and Cyclosporine. Cytokines are produced by the immune system in response to infection and are involved in the regulation of inflammatory and immune responses. Interferon gamma is a pro-inflammatory cytokine generated by helper T-cells, dendritic cells and NK cells. It is an important typical cytokine for innate and adaptive immunity against intracellular bacterial infection, viral infection as well as tumor control. ${ }^{5}$

An acute renal transplant rejection is a critical issue in kidney transplantation that can cause chronic kidney rejection and eventual loss of the transplanted kidney. Transplant rejection is triggered by Thelper cells bearing antigen receptors binding Major Histocompatibility Complex (MHC) class II molecules. Unlike other immunological responses, two T-cell lineages are involved in transplant rejection. Thelper cells respond to $\mathrm{MHC}$ II antigens via proliferation and release pro-inflammatory cytokines (Interferon Gamma) that potentiate the proliferative response of Thelper and T cytotoxic cells. ${ }^{6}$

Obesity is another effective factor in acute rejection of a transplanted kidney. Obesity is a recognized cardiovascular risk factor and is associated with increased risk of mortality in this population.? Metabolic syndrome and obesity can be followed in the pathology of a renal disease. ${ }^{8}$ Obesity significantly reduces the survival of patients and graft; it also directly causes kidney damages as well as chronic renal failure and also, indirectly aggravates arterial hypertension, hypercholesterolemia and cardiovascular diseases, ${ }^{9}$ and the majority of kidney transplant recipients deaths are related to cardiovascular events. Furthermore, it seems that obesity effects on the immune function of lymphocytes and NK cells and reduces their activity. ${ }^{10}$ The lack of physical activities, obesity and lifestyle-related diseases result in chronic low-grade inflammation which are associated with elevating plasma levels of inflammatory markers. ${ }^{11}$ Exercise is currently addressed as a useful therapeutic measure to minimize the defective functional capacity in chronic diseases and it is stated that exercise can have several therapeutic impacts such as reducing weight loss and the fat percentage as well as improving health and the quality of life. The results of a previous study study indicated an improvement in inflammatory markers in kidney transplant patients after 30 minutes acute exercise protocol, but it is not clear, if the long term exercise would have same effect on this population. ${ }^{12}$ The positive effect of exercise training is clear for every one and the advantage of this study is related to the selected population, as there is not much academic research on the effects of exercise training on their immunological markers and physiological parameters.

The influence of immune system factors in rejection of kidney transplant as well as the role of exercise as a non-medical intervention without side effects form an important unaddressed research background. The novelty of this study is related to the type of home based exercises (a combination of aerobic and resistance exercises) being used in this population. This study aimed to determine the effect of 10 weeks of combined exercises on Interferon-Gamma, percentage of fat and BMI of kidney transplant patients. In this research, it was hypothesized that this protocol of exercise training would be effective to decline BF\% and BMI without any changes in the level of IFN- $\gamma$ in kidney transplant patients.

\section{METHODS}

In a randomized controlled experimental design with a pre-test (baseline) and a post-test (after 10 weeks of intervention). Randomization was done according to a computer-generated randomization list.

The participants of this study included patients referred to Shiraz Namazi hospital Kidney transplantation centre in Iran, ages were between 20 and 40 years and met the research criteria who were selected randomly. The sample size calculation was performed using the Statcalc feature of the Epi Info software with the version 3.5.3. For this purpose, of the 50 screened patients a number of 46 patients were selected and randomly divided to the experimental $(n=23)$ and the control $(n=23)$ groups, but there were 2 drop out in control group, one in first week and the other one in second week, because of the personal reasons, and the final number of participants decreased to 44 (experimental=23, control=21). The progress of study presented in the CONSORT_flowchart (Figure 1). The criteria for selecting participants included non-diabetic patients, 2-3 years following successful transplantation, no use of alcohol and caffeine during their sickness, the lack of regular participation in exercise activities and $\mathrm{BMI}>25$. After selecting the patients they were explained the objectives of study, all participants read and signed the consent forms. All participants then completed a questionnaire before being examined by a physician in order to check their medical condition and exclusion criteria. All participations did not consume dietary supplements (e.g., proteins, carbohydrates and amino acids) at least three months before and during this study. ${ }^{13}$ The exclusion criteria included cardiovascular problems and chronic diseases (e.g., heart diseases, strokes, diabetes and cancers), not being able to fulfill initial testing screen 
successfully. The patients used some medicines such as mycophenolate mofetil (CellCept), sandimmune (cyclosporine), Imuran (Azathioprine), and Corticosteroids, with prescription of their medical therapist, and all training process were performed under supervision of medical therapist. The inclusion criteria should be taken into consideration such as the ability to walk, low-intensity running on the treadmill and the ability to pedal on cycle ergometer. ${ }^{14}$ The participants were not allowed to participate in other physical activity exercises during the study and both groups were advised to continue with a normal sleep pattern of approximately 8 hours per night for the duration of the experimental study period. ${ }^{15}$ This study was in agreement with the principle of Helsinki Declaration and approved by the ethical committee in the Shiraz Medical University, Iran (NO: 1390/11/03/899). (Figure 1)

\section{The exercise protocol}

The exercise group participated in an exercise program of three sessions per week for $60-90$ minutes at $40-65 \%$ of predicted maximal heart rate reserve, for a period of 10 weeks. The exercise program was designed based on the instruction of American College of Sports Medicine $(\text { ACSM })^{16}$ under supervision of a certified strength and conditioning specialist (CSCS) with regard to the physical condition of patients in terms of the types, intensity, frequency and repetitions of the exercise after a pilot study verifying the safety, efficiency and simplicity. ${ }^{13}$ Each session included a 15-minute warm-up, 20 minutes of the aerobic exercise, 20 minutes of the resistance exercise, and a 10-minute cool-down including running with a slow pace followed by stretching and light exercises. ${ }^{17}$ The control group did not participate in any exercises during the 10 -week period.

The participants performed the main workout for 35-55 minutes between 10 to 12 a.m. in a circuit consisting of 9-17 stations, with 3-6 circles per session, 1-2 minutes of rest between each station, and 3-5 minutes of rest between circles ${ }^{1}$ which was a combination of aerobic exercises using a bicycle ergometer (Nautilus, Vancouver, Canada), treadmill (Nautilus, Vancouver, Canada) and resistance exercises with free weights (Iron Grip Barbell Company, Santa Ana, Canada). The aerobic exercise was performed on a stationary bicycle or treadmill with a 40$70 \%$ maximum heart rate and the resistance exercise involved $45-65 \%$ intensity of one maximum repetition (1RM). The aerobic exercise was performed with mild- to moderate-intensity corresponding to 40-60\% VO2 max. After 10 minutes of general warm-up exercises and stretching, the resistance exercise group participants started the testing session. The aerobic exercises were performed for 30 minutes with an increase of 10 minutes in duration of every four weeks within 10 weeks. ${ }^{18}$

\section{Blood Sampling}

A blood sample was drawn after 12-14 hours of fasting of both the control and exercise groups to evaluate the level of Interferon Gamma. The subjects were asked to withdraw from doing any intensive exercises up to two days before the test. Blood samples $(5 \mathrm{ml})$ were taken from the brachial vein of the left hand by a trained phlebotomist, between 8-10 a.m, using standard blood collection apparatus after $12 \mathrm{~h}$ of fasting $24 \mathrm{~h}$ before and after training program. Blood samples were collected into $3 \mathrm{ml}$ K2EDTA Vacutainer tubes (BD, Franklin Lakes, NJ) in series and anonymized. After the necessary initial inversion, tubes were incubated, without further agitation. Then, blood samples were centrifuged for $15 \mathrm{~min}$ at $3000 \mathrm{rpm}$ for plasma separation and were stored at $-80^{\circ} \mathrm{C}$ until analysis.

\section{Measurements}

IFN $\gamma$ was measured by the ELISA Kit (IFN gamma Human ELISA Kit, KAC1231, USA) for biochemical analysis.

The body fat percentage of the subjects was calculated using a body composition analyzer (made in USA and using the bioelectrical impedance principle) in a fasting state and after urination according

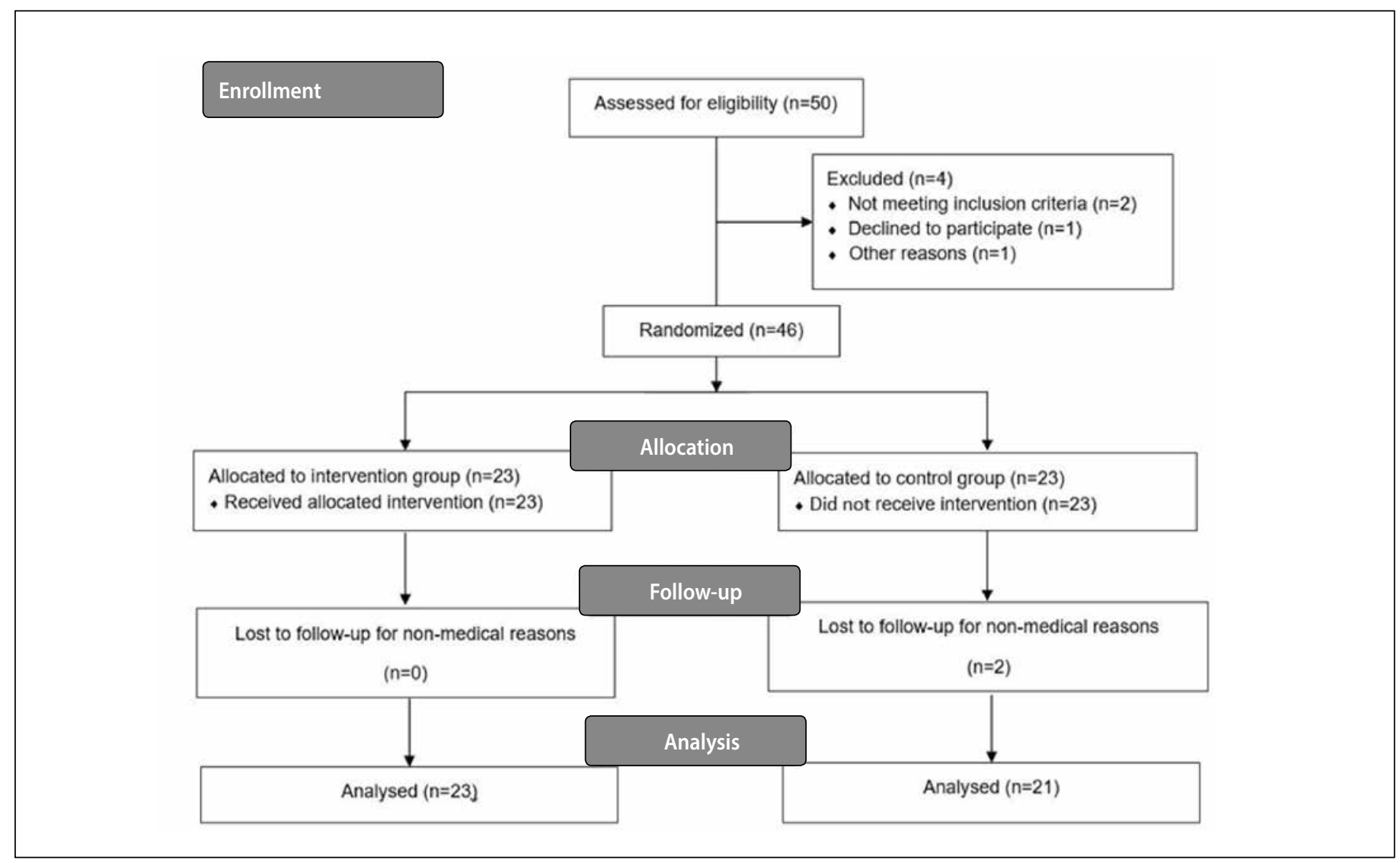

Figure 1. Consort flow chart for recruitment of participation. 
to instructions. After turning on the machine, the subjects were asked to wet their soles and footmark of the machine and then stand on the device and take special handles in hand. The information of their ages and heights (using the Seca stadiometer made in Germany with $0.1 \mathrm{~m}$ sensitivity) as well as the weight of the subjects (by a digital scale of the Pandelectronic model made in Iran with $0.01 \mathrm{~kg}$ sensitivity) were fed into the device and the data were printed after turning on the start button.

\section{Statistical analysis}

Statistical analyses were performed by IBM Statistical Package for Social Sciences (SPSS) Version 22 (Chicago, IL). Prior to data analysis, all variables were subjected to the normality test. Regarding the small number of participants, the Shapiro Wilk test was employed to assess normality of the distribution of scores. Descriptive statistics of the variables was presented by the mean scores and standard deviations ( \pm SDs). Two way repeated measure ANOVA was used to see the changes between the control and experimental groups, A significance level was accepted at the 95\% confidence level for all statistical parameters $(p<0.05)$.

\section{RESULTS}

Data screening indicated that all related assumptions, including the normal distribution of the dependent variables and sphericity (i.e., the homogeneity of variance and covariance), were met as it is shown in Table 1. There were no significant differences between the control and experimental groups in the baseline.

Legend: cm: centimeters; kg: kilograms; bpm: beats per minute.

Comparing exercise and control groups indicated that the intervention had a significant ( $p<0.05$ ) effect on the BMI (from $26.23 \pm 1.81$ to $25.45 \pm 2.11, p=0.001$ ) and BF\% (from 31.80 \pm 5.64 to $28.86 \pm 5.82$, $p=0.001)$ while it was not significant $(p>0.05)$ for Interferon Gamma (from $0.06 \pm 0.02$ to $0.06 \pm 0.02, p=0.829$ ). In addition, there was a significant change in experimental group comparing pre and post 10week intervention $(p<0.01)$ while there was not a significant change in control group $(p>0.05)$ (Table 2$)$.

\section{DISCUSSION}

The findings of this study indicated that 10 weeks of combined exercise training can decrease the percentage of fat and BMI without any significant effect on interferon-gamma (IFN $\gamma$ ) level. So, we can conclude that training would be effective to decline BF\% and BMI without any

Table 1. Demographic and Baseline Characteristics of Participants in Both Groups

\begin{tabular}{c|c|c|c}
\hline Variables & $\begin{array}{c}\text { Exercise } \\
\mathbf{( n = 2 3 )} \\
\text { Mean } \pm \text { SD }\end{array}$ & $\begin{array}{c}\text { Control } \\
(\mathbf{n = 2 3 )} \\
\text { Mean } \pm \text { SD }\end{array}$ & P \\
\hline Age (years) & $38.75 \pm 9.44$ & $36.93 \pm 8.71$ & 0.451 \\
\hline Weight (kg) & $69.95 \pm 7.51$ & $68.50 \pm 8.45$ & 0.742 \\
\hline Height (cm) & $163.12 \pm 5.73$ & $163.68 \pm 3.96$ & 0.120 \\
\hline Medical History & $13.06 \pm 10.40$ & $12.21 \pm 5.14$ & 0.081 \\
Resting heart rate (bpm) & $75.28 \pm 4.13$ & $75.21 \pm 4.42$ & 0.761 \\
\hline **Values are presentad as means +SD & & &
\end{tabular}

Table 2.Comparison of Effects of Combined Exercise Training on Interferon-Gamma (IFNY), Percentage of Fat and BMI between Exercise and Control Groups.

\begin{tabular}{|c|c|c|c|c|c|c|c|}
\hline \multirow{2}{*}{ Variables } & \multicolumn{2}{|c|}{$\begin{array}{c}\text { Exercise }(n=23) \\
\text { Mean } \pm S D\end{array}$} & \multirow{2}{*}{$\mathrm{p}^{*}$} & \multicolumn{2}{|c|}{$\begin{array}{c}\text { Control }(n=21) \\
\text { Mean } \pm S D\end{array}$} & \multirow{2}{*}{$p^{*}$} & \multirow{2}{*}{$P$} \\
\hline & Baseline & $\begin{array}{c}\text { After } 10 \\
\text { weeks }\end{array}$ & & Baseline & $\begin{array}{l}\text { After } 10 \\
\text { weeks }\end{array}$ & & \\
\hline BMI (kg/m2) & $26.23 \pm 1.81$ & $25.45 \pm 2.11$ & 0.001 & $25.56 \pm 3.09$ & $25.88 \pm 3.11$ & 0.691 & 0.001 \\
\hline BFP (\%) & $31.80 \pm 5.64$ & $28.86 \pm 5.82$ & 0.001 & $26.27 \pm 4.24$ & $26.40 \pm 4.29$ & 0.720 & 0.002 \\
\hline IFNy (pg/ml) & $0.06 \pm 0.02$ & $0.06 \pm 0.02$ & 0.829 & $0.08 \pm 0.04$ & $0.08 \pm 0.04$ & 0.262 & 0.124 \\
\hline
\end{tabular}

changes in the level of IFN- $\gamma$ among kidney transplant patients. Gamma interferon (IFN- $\gamma$ ) is a pro-inflammatory cytokine generated by T cytotoxic cells, CD4 T-cells and NK cells following the activation of the immune system and inflammatory stimuli which acts against viral and bacterial infections. This cytokine inhibits the viral replication (resistance against viruses), increases the expression of class I and II MHC molecules, and thus, enhances the recognition of antigen by $T$ cytotoxic and NK cells as well as stimulating cytotoxicity, antibacterial activities and the antigen presentation in macrophages. ${ }^{19}$ Several reports indicate the different impacts of exercises on the level of this cytokine. A body of research has currently conducted in laboratories to evaluate the effects of exercise activities on immune system responses. ${ }^{20}$ Physical activities increase the capacity of oxidative enzymes in muscles due to increased density of mitochondria. ${ }^{21}$ In addition, increased activities of electron transport chain enzymes enhance the activity of enzymes involved in the oxidation of fat, in particular the beta-oxidation cycle enzymes and protein lipase.

Several studies have reported that kidney transplant patients had a poor fitness level in relation to the body composition and can improve their exercise performance and body composition via participating in exercise programs, ${ }^{22}$ and so support the findings of current research. In view of the weight and fat loss, more frequent workouts per week, long runtime of exercises as well as exercise with an intensity supplied by energy from an aerobic/anaerobic device along with proper controlled diet can be effective, ${ }^{23}$ and this was the reason for choosing a combination of aerobic and resistance exercise in current study. The results obtained by Wang \& and Ann ${ }^{24}$ were accordance with the current study findings. The findings of this research were also consistent with Gutin et al. that observed eight weeks of endurance training caused significant changes in the BMI and fat percentage of obese individuals. ${ }^{25}$

In addition, the results of current study were not consistent with the findings of a number of studies including Golzari et al., ${ }^{23}$ showed that eight weeks of combined strength-endurance exercises in women with atherosclerosis led to a significant decrease in the IFN- $\gamma$ level, and most probably, it could be related to the other physiological parameters. Wang et al., showed that 12 weeks of exercise training caused no changes in the IFN- $\gamma$ leve $\left.\right|^{24}$ and did not reduce the inflammatory markers. The findings of Wang support the findings of this research. However, the findings of Golzari et al., revealed that eight weeks of compound training had useful anti-inflammatory effects by reducing the production of IFN- $\gamma$ and IL$17 .{ }^{23}$ The differences between the findings of current research and the study of Golzari et al, could be related to the different types of subjects, as the subjects of current study were the kidney transplant patients with limited ability in performing physical activity and the intensity of their exercise was lower than those researches. ${ }^{23}$ It seems that the differences in the various reports concerning the response of IFN level to exercise activities is due to some factors such as the use of different protocols with various variables and training intensities, ${ }^{26}$ subjects with diverse physical and exercise conditions (e.g., kidney transplant patients in this study), environmental conditions, age groups, gender ${ }^{27}$ as well as spiritual-psychological conditions of subjects that were different in various studies and caused contradictory results.

It seems that the impact of immunosuppressive agents as well as factors potentiating the immune system (selected physical activities) has been to the extent that the IFN- $\gamma$ level has not changed in kidney transplant patients. In general, high concentration of the proinflammatory cytokine (IFN- $\gamma$ ) in patients is associated with the intensification of clinical symptoms and disease relapse phases. It appears that unchanged the IFN- $\gamma$ concentration compared to the other above-mentioned studies on healthy individuals, athletes and other patients may be due to the low intensity, duration and types of exercise activities and more important the administered drugs. 
The profile of immune system response to exercise activities demands further studies in longer periods of intervention as well as the evaluation of factors affecting it. The lack of diet control in subjects, physical activities outside training sessions as well as the level of stress and anxiety during the study were other limitations that should be taken into consideration in future research. In addition, this study only measured interferon as an immune biomarker and $\mathrm{BF} \%$ and $\mathrm{BMI}$ as anthropometric characteristics, so considering other indices of immune system or anthropometric measures are recommended for further clarification.

\section{CONCLUSION}

It can be stated that 10 weeks of combined exercise cannot change the Interferon Gamma level significantly in renal transplant patients but can affect the fat percentage and body mass index in this population. As a practical message, it should be mentioned that, combined exercise intervention is as performed in current study can be recommended to the kidney transplant patients to decrease their weight and BF\% without any side effects on their immune system. Evaluating influence of various durations and intensities of exercise training and also measuring other immune indices are suggested for future researches.

\section{ACKNOWLEDGMENT}

The authors would like to thank the University of Malaya Research Management and Monitoring Research - PG169-2014B for partly funding this project. We would also like to express our deep and sincere gratitude to Professor Dr. Jamshid Roozbeh, for providing invaluable guidance throughout this research. Our special appreciation goes to all the laboratory staff of laboratory Namazi hospital in Shiraz for their kindness and support during our research work.

All authors declare no potential conflict of interest related to this article.

AUTHORS' CONTRIBUTIONS: Each author made significant individual contributions to this manuscript. ES (0000-0002-8700-7824)* article conception, design and data gathering; HS (0000-0002-5602-1754)* drafting of data analysis of the article; MHK (0000-0002-2435-6277)* supervision of laboratory for data; MS (0000-0003-2969-9102)*, MK (0000-0001-9563-9461)*, and AY (0000-0002-8117-6440)* final approval of the article. *ORCID (Open Researcher and Contributor ID).

\section{REFERENCES}

1. Pooranfar S, Shakoor E, Shafahi M, Salesi M, Karimi M, Roozbeh J, et al. The Effect of Exercise Training on Quality and Quantity of Sleep and Lipid Profile in Renal Transplant Patients: A Randomized Clinical Trial. Int J Organ Transplant Med. 2014;5(4):157-65.

2. Couchoud C, Couillerot A-L, Dantony E, Elsensohn MH, Labeeuw M, Villar E, et al. Economic impact of a modification of the treatment trajectories of patients with end-stage renal disease. Nephrol Dial Transplant. 2015;30(12):2054-68.

3. Shakoor E, Jahromi MK, Salesi M, Sadeghi H. The Effects of 10 Weeks Concurrent Aerobic and Strength Exercise on Quality of Life and Resilience of Kidney Transplant Patients. Int J Appl Exe Phy. 2015;4(2):1-8.

4. Matas AJ, Smith JM, Skeans MA, Thompson B, Gustafon SK, Schnitzler MA, et al. OPTN/SRTR 2012 annual data report: kidney. Am J Transplant. 2014;14(Suppl 1):11-44.

5. Abbas AK, Lichtman AHH, Pillai S. Cellular and molecular immunology. Amsterdan: Elsevier Health Sciences; 2014.

6. Nankivell BJ, Borrows RJ, Fung CLS, O'Connell PJ, Allen RD, Chapman JR. Natural history, risk factors, and impact of subclinical rejection in kidney transplantation. Transplantation. 2004;78(2):242-9.

7. Prospective Studies C. Body-mass index and cause-specific mortality in 900000 adults: collaborative analyses of 57 prospective studies. Lancet. 2009;373(9669):1083-96.

8. Ducloux D, Kazory A, Simula-Faivre D, Chalopin JM. One-Year Post-Transplant Weight Gain is a Risk Factor for Graft Loss. Am J Transplant. 2005;5(12):2922-8.

9. Segev DL, Simpkins CE, Thompson RE, Locke JE, Warren DS, Montgomery RA. Obesity impacts access to kidney transplantation. J Am Soc Nephrol. 2008;19(2):349-55.

10. Moriguchi S, Oonishi K, Kato M, Kishino Y. Obesity is a risk factor for deteriorating cellular immune functions decreased with aging. Nutr Res. 1995;15(2):151-60.

11. Fischer CP, Berntsen A, Perstrup LB, Eskildsen P, Pedersen BK. Plasma levels of interleukin- 6 and C-reactive protein are associated with physical inactivity independent of obesity. Scand J Med Sci Sports. 2007;17(5):580-7.

12. Coletta DK, Campbell LE, Weil J, Kaplan B, Clarkson M, Finlayson J, et al. Changes in Pre-and Post-Exercise Gene Expression among Patients with Chronic Kidney Disease and Kidney Transplant Recipients. PloS one. 2016;11(8):e0160327.

13. Shariat A, Kargarfard M, Danaee M, Tamrin SBM. Intensive resistance exercise and circadian salivary testosterone concentrations among young male recreational lifters. J Strength Cond Res. 2015;29(1):151-8

14. Ulubay G, Akman B, Sezer S, Calik K, Eyuboglu Oner F, Ozdemir N, et al. Factors Affecting Exercise Capacity in Renal Transplantation Candidates on Continuous Ambulatory Peritoneal Dialysis Therapy. Transplant Proc. 2006;38(2):401-5.
15. Kargarfard M, Lam ETC, Shariat A, Shaw I, Shaw BS, Tamrin SB. Efficacy of massage on muscle soreness, perceived recovery, physiological restoration and physical performance in male bodybuilders. $J$ Sports Sci. 2016;34(10):959-65.

16. Chodzko-Zajko W, American College of Sports M. ACSM's exercise for older adults. Philadelphia: Lippincott Williams \& Wilkins; 2013.

17. Sadeghi H, Hakim MN, Hamid TA, Amri SB, Razeghi M, Farazdaghi M, et al. The effect of exergaming on knee proprioception in older men: A randomized controlled trial. Arch Gerontol Geriatr. 2017;69:144-50.

18. Baria F, Kamimura MA, Aoike DT, Ammirati A, Rocha ML, de Melo MT, et al. Randomized controlled trial to evaluate the impact of aerobic exercise on visceral fat in overweight chronic kidney disease patients. Nephrol Dial Transplant. 2014;29(4):857-64.

19. Thomson AW, Lotze MT. The Cytokine Handbook, Two-Volume Set. Hudson, Texas: Gulf Professional Publishing; 2003

20. Jeurissen A, Bossuyt X, Ceuppens JL, Hespel P. [The effects of physical exercise on the immune system] Ned Tijdschr Geneeskd. 2003;147(28):1347-51.

21. Irving BA, Lanza IR, Henderson GC, Rao RR, Spiegelman BM, Nair KS. Combined training enhances skeletal muscle mitochondrial oxidative capacity independent of age. J Clin Endocrinol Metab. 2015;100(4):1654-63.

22. Johansen KL, Painter PL, Sakkas GK, Gordon P, Doyle J, Shubert T. Effects of resistance exercise training and nandrolone decanoate on body composition and muscle function among patients who receive hemodialysis: a randomized, controlled trial. J Am Soc Nephrol. 2006;17(8):2307-14.

23. Golzari Z, Shabkhiz F, Soudi S, Kordi MR, Hashemi SM. Combined exercise training reduces IFN- $\gamma$ and $\mathrm{LL}-17$ levels in the plasma and the supernatant of peripheral blood mononuclear cells in women with multiple sclerosis. Int Immunopharmacol. 2010;10(11):1415-9.

24. Wang MY, An LG. Effects of 12 weeks'tai chi chuan practice on the immune function of female college students who lack physical exercise. Biol Sport. 2011;28(1):45-9

25. Gutin B, Barbeau P, Owens S, Lemmon CR, Bauman M, Alison J, et al. Effects of exercise intensity on cardiovascular fitness, total body composition, and visceral adiposity of obese adolescents. Am J Clin Nutr. 2002;75(5):818-26.

26. Shimizu K, Kimura F, Akimoto T, Akama T, Tanabe K, Nishijima T,et al. Effect of moderate exercise training on T-helper cell subpopulations in elderly people. Exerc Immunol Rev. 2008;14:24-37.

27. Gopal A, Mondal S, Gandhi A, Arora S, Bhattacharjee J. Effect of integrated yoga practices on immune responses in examination stress-A preliminary study. Int J Yoga. 2011;4(1):26-32. 